\title{
Klasifikasi Penyakit Mata Berdasarkan Citra Fundus Retina Menggunakan Dimensi Fraktal Box Counting Dan Fuzzy K-Means
}

\author{
Ayu Evilia Suwanda ${ }^{1}$, Dwi Juniati ${ }^{2}$ \\ Universitas Negeri Surabaya ${ }^{1,2}$ \\ Email: ayu.18046@mhs.unesa.ac.id ${ }^{1}$,dwijuniati@unesa.ac.id ${ }^{2}$
}

\begin{abstract}
Abstrak. Mata merupakan salah satu panca indera yang sangat penting dalam keberlangsungan hidup manusia. Mata berfungsi sebagai indera penglihatan yang sangat sensitif. Jika mata mengalami gangguan atau penyakit mata, maka akibatnya dapat mengganggu aktivitas sehari-hari. Bermacam jenis penyakit dapat menyerang mata, untuk menyembuhkannya dibutuhkan deteksi jenis penyakit dengan tepat supaya dapat ditentukan pengobatan yang sesuai. Untuk membedakan berbagai macam penyakit mata tersebut dapat dilihat melalui foto fundus retina. Foto fundus retina adalah prosedur pengambilan gambar pada bagian fundus retina. Tindakan foto fundus retina dapat menangkap gambaran pada daerah di belakang mata yang meliputi retina, saraf mata (saraf optikus), macula, dan pembuluh darah retina. Tujuan penelitian ini adalah melihat apakah dimensi box counting pada foto fundus retina dapat digunakan untuk mendeteksi jenis penyakit pada mata. Penyakit mata dalam penelitian ini adalah katarak, glaucoma dan penyakit retina. Data yang digunakan sebanyak 100 citra fundus retina. Metode yang digunakan adalah proses segmentasi dari citra fundus retina menggunakan tahapan green chanel, CLAHE, Morphological Opening dan Matched Filter yang hasilnya berupa bercak pembuluh darah pada retina, selanjutnya, digunakan metode box counting untuk menghitung nilai dimensinya dan proses klasifikasi dengan fuzzy k-means. Berdasar hasil penelitian diperoleh hasil akurasi sebesar $76 \%$ sehingga disimpulkan bahwa dimensi fraktal box counting pada foto fundus retina dapat digunakan untuk menentukan jenis penyakit mata.
\end{abstract}

\section{Kata Kunci: Citra Fundus Retina, Box Counting, Fuzzy K-Means}

\begin{abstract}
Eyes are one of the five senses that are very important in human life. The eye functions as a very sensitive sense of sight. If the eye has eye disorders or eye disease, then the consequences can interfere with daily activities. Various types of diseases can attack the eye, to cure it, it is necessary to detect the type of disease correctly so that the appropriate treatment can be determined. To distinguish various kinds of eye diseases can be seen through the retinal fundus photo. Retinal fundus photo is a procedure of taking pictures of the fundus of the retina. Retinal fundus photography can capture images of the area at the back of the eye which includes the retina, eye nerve (optic nerve), macula, and retinal blood vessels. The purpose of this study was to see whether the box counting dimensions on retinal fundus photos could be used to detect types of eye disease. The eye diseases in this study were cataract, glaucoma and retinal disease. The data used are 100 retinal fundus images. The method used is the segmentation process of the retinal fundus image using the stages of green channel, CLAHE, Morphological Opening and Matched Filter which results in the form of blood vessel spots on the retina, then, box counting method is used to calculate the dimension value and classification process with fuzzy k-means. Based on the results of the study, the accuracy of $76 \%$ was obtained, so it was concluded that the box counting fractal dimensions on retinal fundus photos can be used to determine the type of eye disease.
\end{abstract}

Keywords: Fundus Retina Image, Box Counting, Fuzzy K-Means.

\section{A. PENDAHULUAN}

Mata merupakan salah satu panca indera yang sangat penting dalam keberlangsungan hidup manusia. Mata adalah organ penglihatan yang mendeteksi cahaya. Hal sederhana yang dilakukan mata adalah membedakan antara gelap dan terang. Retina merupakan bagian mata yang kompleks dan paling sensitive terhadap cahaya. Retina mengandung reseptor untuk meneruskan rangsangan cahaya yang diterima dalam bentuk bayangan. Hal tersebut yang membuat seseorang dapat melihat. Apabila mata mengalami gangguan atau penyakit mata, dapat berakibat terganggunya aktivitas sehari-hari. Gangguan pada penglihatan mata banyak terjadi, 
mulai dari ringan sampai yang berat. Penyakit yang menyerang indera penglihatan sangat banyak jenisnya. Beberapa contoh diantaranya adalah katarak, glaucoma, penyakit retina.

Katarak ditandai dengan penglihatan mata yang buram akibat penuaan atau bertambahnya usia. Fungsi penglihatan mengalami penurunan dikarenakan lensa mata mengalami kekeruhan. Kekeruhan pada mata terjadi karena protein pada mata membentuk sebuah gumpalan (Munarto \& Yudono, 2019). Akan tetapi katarak juga bisa dialami pada kelompok usia muda dikarenakan penumpukan glukosa yang dipicu oleh penyakit diabetes. Gangguan mata tersebut dapat menjadi penyebab kebutaan pada manusia. Katarak juga merupakan salah satu penyumbang angka kebutaan terbanyak di dunia. Pada penderita katarak, pembuluh darah mata tidak terlihat jelas. Hal tersebut dikarenakan lensa mata yang keruh dan terlihat seperti tertutupi awan.

Glaukoma adalah kerusakan pada saraf mata yang terjadi karena tekanan tinggi pada bola mata. Tekanan tinggi dapat terjadi akibat produksi cairan pada bola mata yang berlebihan (Mustofa dkk, 2016). Glaukoma merupakan penyumbang kedua tertinggi penyebab kebutaan setelah katarak. Karakteristik fundus retina pada penderita glaukoma sangat mirip dengan penderita katarak yaitu lensa mata terlihat keruh. Namun, kekeruhan lensa pada penderita glaukoma tidak sekeruh pada penderita katarak.

Penyakit Retina (Retina Disease) merupakan penyakit mata yang menyerang retina. Gejala pada penyakit retina ditandai dengan penglihatan kabur, pandangan bergaris, bahkan dapat menyebabkan kehilangan penglihatan. Penyakit retina dapat terjadi kepada siapa saja. Akan tetapi yang memiliki resiko tinggi terkena adalah seseorang yang berusia lebih dari 40 tahun, mempunyai riwayat penyakit retina, dan penderita diabetes/hipertensi Karakteristik penyakit retina yaitu terdapat bercak-bercak pada lensa mata sehingga pembuluh darah retina tidak terlihat dengan jelas.

Berikut ini diberikan foto fundus retina pada mata normal, katarak, glaucoma, penyakit retina yang terdapat pada Kaggle dataset.

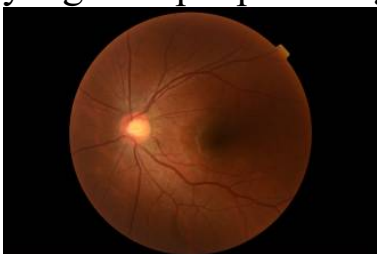

(a).

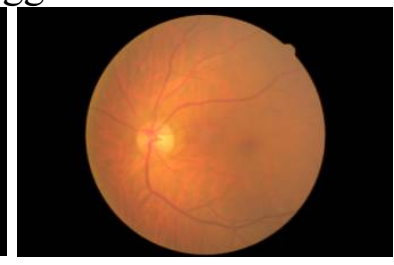

(b).

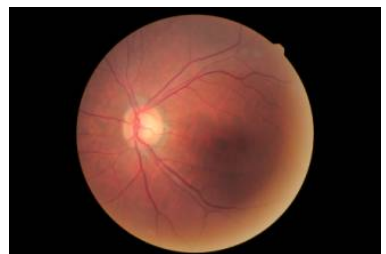

(c).

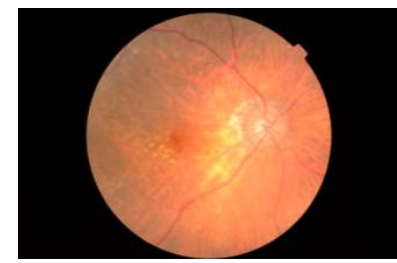

(d).

Gambar 1. Foto fundus retina (a). mata normal, (b) katarak, (c). Glaukoma, (d). Penyakit retina.

Foto fundus mata adalah prosedur pengambilan gambar pada bagian fundus mata. Tindakan foto fundus mata dapat menangkap gambaran pada daerah di belakang mata yang meliputi retina, saraf mata (saraf optikus), makula, dan pembuluh darah retina. Karakteristik fundus retina pada mata normal yaitu bola mata terlihat jernih dan pembuluh darah terlihat dengan jelas. Perbedaan struktur pembuluh darah dapat digunakan untuk menentukan gangguan-gangguan pada mata.

Perkembangan teknologi yang pesat harusnya bisa dimanfaatkan untuk mempermudah tenaga kesehatan dalam deteksi dini mengetahui jenis penyakit mata dengan memanfaatkan foto fundus retina. Segmentasi citra merupakan suatu penggunaan teknologi yang bertujuan memisahkan suatu objek dengan backgroundnya. Pembagian citra berdasarkan wilayah (region) yang memiliki kemiripan tingkat keabuan piksel disekitarnya (Fitriani, 2017). Aplikasi segmentasi citra di dunia medis salah satunya adalah segmentasi citra fundus retina.

Proses segmentasi citra bertujuan untuk memisahkan objek yang akan diamati dengan objek lain yang tidak dibutuhkan (Asril dkk, 2019). Segmentasi citra dilakukan untuk memperoleh informasi yang terdapat dalam citra tersebut. Pemisahan objek berguna untuk mendapatkan objek-objek tertentu yang dibutuhkan dalam proses segmentasi. Citra akan dipisahkan sesuai dengan keseragaman kriteria. Pada proses segmentasi ini dapat dilakukan dengan tahapan proses Green Channel, Clahe, Morphological Opening, Matched Filter dan Masking. 
Fraktal merupakan cabang matematika yang cukup baru yang mempelajari bentukbentuk yang tidak teratur yang tidak dapat dipahami melalui geometri klasik. Fraktal diartikan patah, pecah atau tidak teratur. Selain sifat dari fraktal yang dapat digunakan untuk membentuk bermacam obyek alam, maka karakteristik penting lainnya adalah dimensi fraktal yang bisa berupa pecahan (Juniati dan Ketut, 2016). Geometri fraktal dapat digunakan untuk menganalisa objek yang tidak beraturan dengan menentukan dimensi obyek tersebut. Salah satu metode penghitungan dimensi fractal adalah box counting. Dimensi metode ini telah banyak diaplikasikan pada berbagai bidang. Alifa dan Juniati (2019) menentukan jenis penyakit kanker kulit dengan mengggunakan dimensi box counting. Juniati dkk (2018) menentukan jenis penyakit jantung berdasar dimensi fractal dari suara jantung. Safitri (2017) menggunakan dimensi fractal untuk mendeteksi penyakit retinophaty. Juniati dkk (2021) menggunakan dimensi box counting untuk recognisi iris mata pada orang kembar. Struktur pembuluh darah di retina berupa bentuk tidak regular yang mempunyai kemiripan bentuk pada skala yang berbeda. Hal ini merupakan salah satu karakteristik dari objek fraktal. Oleh karena itu, metode perhitungan dimensi fraktal dapat diterapkan pada pembuluh darah retina.

Berdasar hasil di atas, maka penelitian ini bertujuan melihat apakah metode penghitungan dimensi fraktal pada citra fundus retina dapat digunakan dalam deteksi penyakit mata dengan menggunakan klasifikasi fuzzy k-means.

Pada penelitian ini, metode box counting digunakan untuk mencari nilai dimensi citra fundus retina. Perhitungan dimensi dapat diperoleh dengan persamaan sebagai berikut:

$$
\operatorname{Dim}=\frac{\log (N(r))}{\log \left(\frac{1}{r}\right)}
$$

Dengan N(r) = jumlah kotak yang berisikan citra, $r=$ rasio panjang segmen.

Algoritma Fuzzy k-means merupakan bagian dari algoritma analisis kluster non hierarki. Tujuan dari k-means clustering adalah untuk mengelompokkan sejumlah data berdasarkan tingkat kemiripan dari masing-masing data. Langkah awal yang dilakukan dalam pengklasteran yaitu menentukan jumlah klaster yang diinginkan. Selanjutnya menentukan pusat klaster dan menghitung jarak setiap data terhadap pusat klaster menggunakan rumus Euclidian. (Katwarti, 2017):

$$
D(i, j)=\sqrt{\left(X_{1 i}-X_{1 j}\right)^{2}+\cdots+\left(X_{k i}-X_{k j}\right)^{2}}
$$

Dimana,

$\boldsymbol{D}(\boldsymbol{i}, \boldsymbol{j})=$ jarak data ke $i$ ke pusat cluster $j$

$\boldsymbol{X}_{\boldsymbol{k} \boldsymbol{i}}=$ data ke $i$ pada atribut data ke $k$

$\boldsymbol{X}_{\boldsymbol{k} \boldsymbol{j}} \quad=$ titik pusat ke $j$ pada atribut ke $k$

\section{B. METODOLOGI PENELITIAN}

Dalam penelitian ini digunakan data sekunder yang diperoleh dari kaggle dataset. Data tersebut berupa 100 citra fundus retina yang terdiri dari 25 citra mata normal, 25 citra katarak, 25 citra glaucoma, dan 25 citra penyakit retina. Prosedur penelitian dilakukan seperti yang digambarkan pada bagan berikut. 


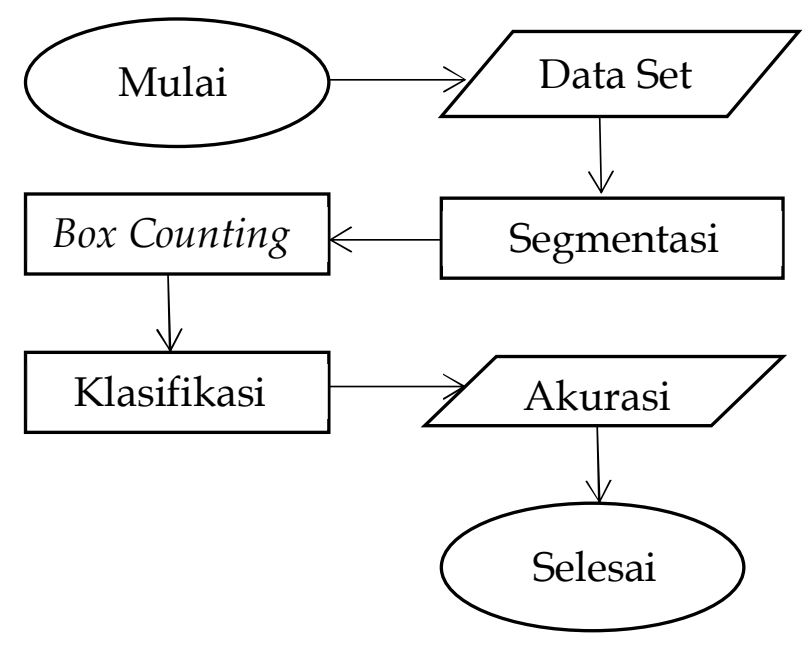

\section{a. Data Set}

Data penelitian berupa 100 citra fundus retina diinputkan dan diproses satu per satu.

\section{b. Segmentasi}

Pada proses segmentasi citra fundus retina akan diolah dengan bantuan software Matlab melalui 5 tahapan sebagai berikut:

- Green Channel

Citra RGB (Red, Green, Blue) merupakan citra yang nilai intensitas pikselnya tersusun dari tiga kanal warna yaitu merah, hijau, dan biru. Pada penelitian kali ini, kanal warna hijau dipilih untuk diekstraksi karena menunjukkan intensitas paling tinggi dari warna merah dan biru.

- CLAHE

Clahe digunakan untuk meningkatkan kualitas gambar yang telah melalui proses green channel. Pembuluh darah retina akan terlihat lebih detail pada proses ini.

- Morphological Opening

Untuk menghaluskan objek dan menghilangkan objek yang bukan merupakan pembuluh darah adalah fungsi dari morphological opening.

- $\quad$ Matched Filter

Pendeteksian pembuluh darah pada retina dapat dilakukan memalui proses matched filter.

Dimensi Box Counting

Pada proses ini hasil dari segmentasi citra fundus retina akan dicari nilai dimensinya. Hasil dari dimensi citra fundus retina digunakan untuk proses penentuan klaster.

\section{c. Klasifikasi}

Klasifikasi merupakan proses pengelompokan. Fuzzy k-means digunakan untuk memproses pengelompokan atau klasifikasi nilai dimensi box counting yang diperoleh dari proses sebelumnya.

d. Akurasi

Proses akurasi dari hasil klasifikasi citra fundus retina dapat dihitumg sebagai berikut:

$$
\text { Akurasi }=\frac{\text { Jumlah data benar }}{\text { jumlah data keseluruhan }} \times 100 \%
$$




\section{HASIL PENELITIAN DAN PEMBAHASAN}

Proses pengolahan data dilakukan pada 100 data citra fundus retina. Proses segmentasi yang melalui tahap green channel, proses CLAHE, morphological opening dan matched filter dilakukan pada setiap citra fundus. Hasil pengolahan tiap tahap dari proses tersebut diberikan berikut ini untuk citra fundus retina mata normal, citra fundus retina penderita kataral, citra fundus retina penderita glaucoma dan citra fundus retina penderita penyakit retina.

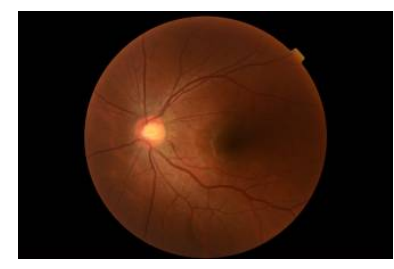

(a)

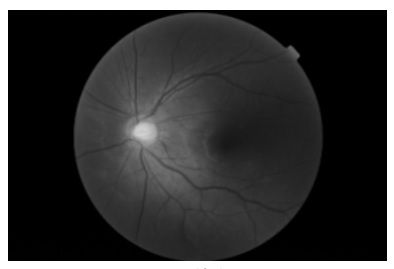

(b)

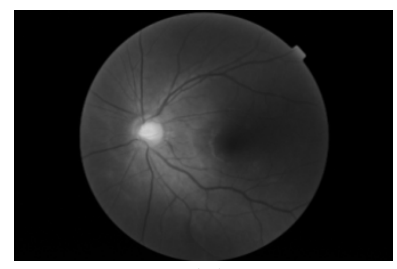

(c)

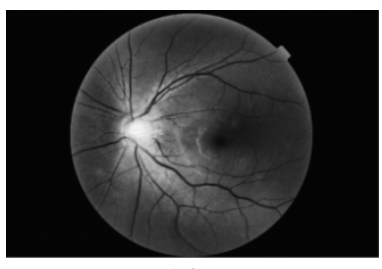

(d)

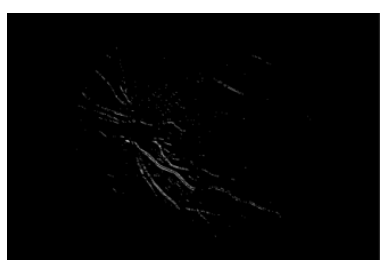

(e)

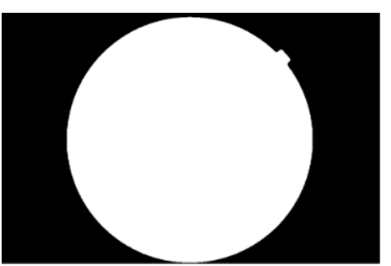

(f)

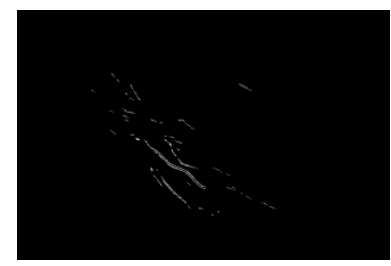

(g)

Gambar 2. Pengolahan Citra Mata Normal

Pada gambar 2 ditunjukkan proses pengolahan citra fundus retina pada mata normal. Gambar (a) menunjukkan citra asli dari mata normal, gambar (b) menunjukkan citra fundus retina hasil dari proses green channel, gambar (c) menunjukkan citra fundus retina hasil dari proses clahe, gambar (d) menunjukkan citra fundus retina hasil dari proses morphological opening, gambar (e) menunjukkan citra fundus retina hasil dari proses matched filter, gambar (f) menunjukkan citra fundus retina hasil dari proses masking, dan gambar (g) menunjukkan hasil dari segmentasi citra fundus retina mata normal.

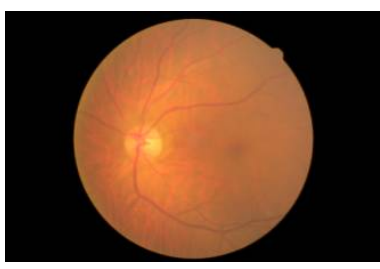

(a)

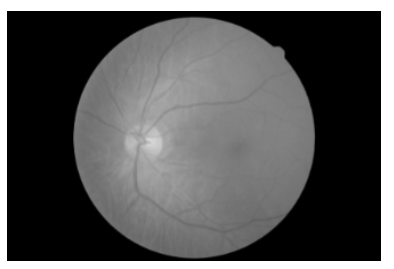

(b)

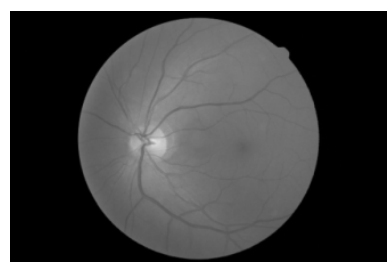

(c)

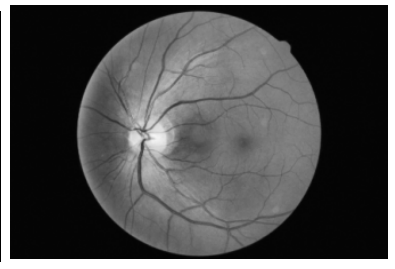

(d)

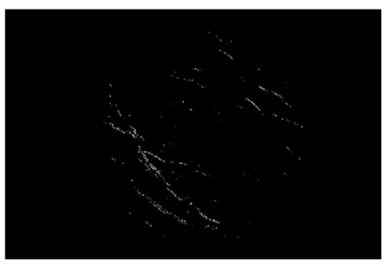

(e)

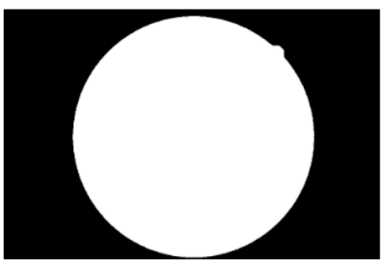

(f)

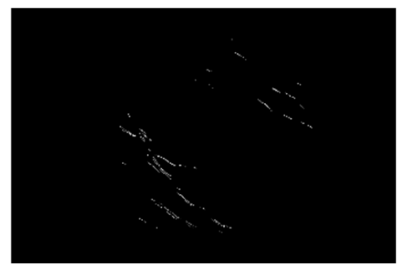

(g)

Gambar 3. Pengolahan Citra Penderita Katarak

Pada gambar 3 ditunjukkan proses pengolahan citra fundus retina pada penderita katarak. Gambar (a) menunjukkan citra asli dari penderita katarak, gambar (b) menunjukkan citra fundus retina hasil dari proses green channel, gambar (c) menunjukkan citra fundus retina hasil dari 
proses clahe, gambar (d) menunjukkan citra fundus retina hasil dari proses morphological opening, gambar (e) menunjukkan citra fundus retina hasil dari proses matched filter, gambar (f) menunjukkan citra fundus retina hasil dari proses masking, dan gambar (g) menunjukkan hasil dari segmentasi citra fundus retina penderita katarak.

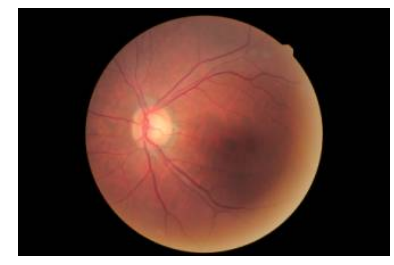

(a)

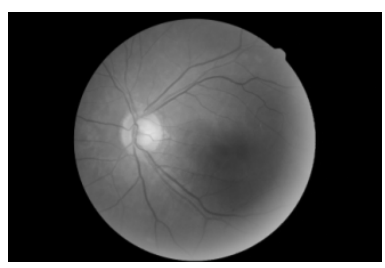

(b)

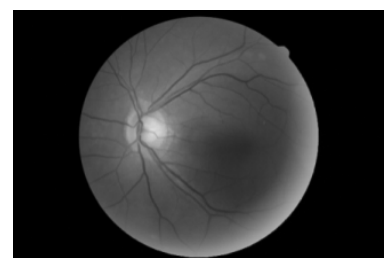

(c)

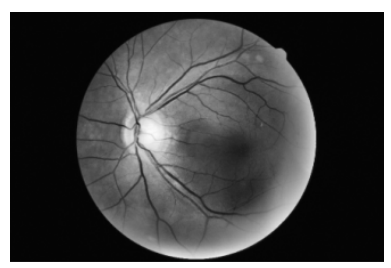

(d)

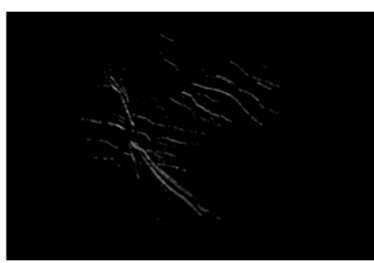

(e)

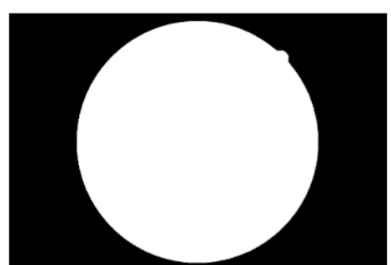

(f)

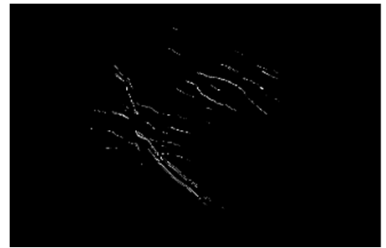

$(\mathrm{g})$

Gambar 4. Pengolahan Citra Penderita Glaukoma

Pada gambar 4 ditunjukkan proses pengolahan citra fundus retina pada penderita glaukoma. Gambar (a) menunjukkan citra asli dari penderita glaukoma, gambar (b) menunjukkan citra fundus retina hasil dari proses green channel, gambar (c) menunjukkan citra fundus retina hasil dari proses clahe, gambar (d) menunjukkan citra fundus retina hasil dari proses morphological opening, gambar (e) menunjukkan citra fundus retina hasil dari proses matched filter, gambar (f) menunjukkan citra fundus retina hasil dari proses masking, dan gambar (g) menunjukkan hasil dari segmentasi citra fundus retina penderita glaukoma.

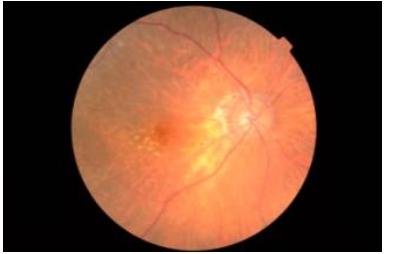

(a)

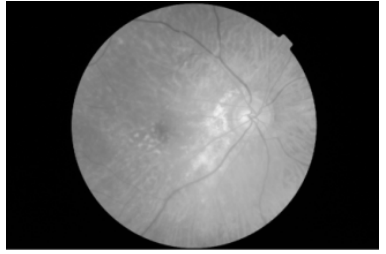

(b)

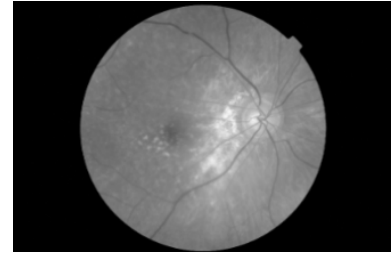

(c)

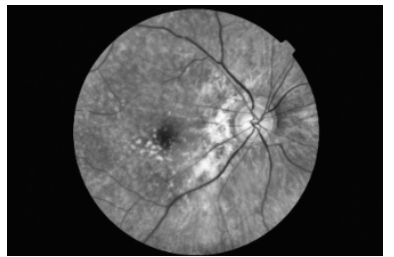

(d)

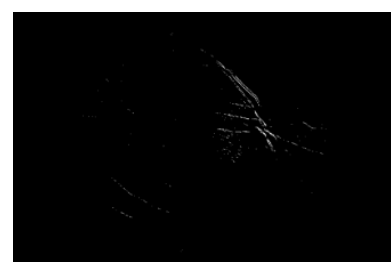

(e)

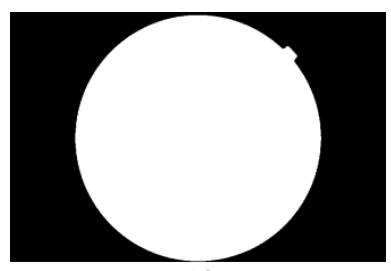

(f)

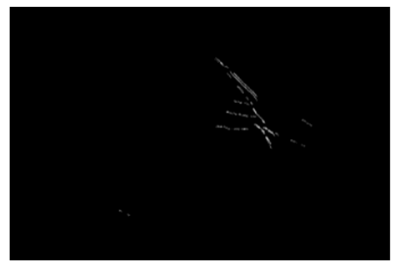

(g)

Gambar 5. Pengolahan Citra Penderita Penyakit Retina (Retina Disease)

Pada gambar 5 ditunjukkan proses pengolahan citra fundus retina pada penderita penyakit retina. Gambar (a) menunjukkan citra asli dari penderita penyakit retina, gambar (b) menunjukkan citra fundus retina hasil dari proses green channel, gambar (c) menunjukkan citra fundus retina hasil dari proses clahe, gambar (d) menunjukkan citra fundus retina hasil dari 
proses morphological opening, gambar (e) menunjukkan citra fundus retina hasil dari proses matched filter, gambar (f) menunjukkan citra fundus retina hasil dari proses masking, dan gambar (g) menunjukkan hasil dari segmentasi citra fundus retina penderita penyakit retina.

Hasil dari pengolahan segmentasi untuk tiap citra fundus retina diproses untuk dihitung dimensi fraktal box counting. Tabel 1 menunjukkan rata-rata dimensi fraktal box counting untuk tiap kelompok.

Tabel 1. Rata-rata Nilai Dimensi Fractal masing-masing Citra Fundus Retina

\begin{tabular}{ccc}
\hline No. & Jenis Penyakit & Nilai Dimensi \\
\hline 1 & Mata Normal & 1.2622 \\
2 & Katarak & 1.1020 \\
3 & Glaukoma & 1.1589 \\
4 & Penyakit Retina & 1.4235 \\
\hline
\end{tabular}

Langkah berikutnya adalah mengklasifikasi data dimensi fraktal box counting ke dalam kelompok-kelompok dengan menggunakan metode fuzzy k-means dengan bantuan software RapidMiner Studio. Dari hasil klasifikasi diperoleh pusat kluster yang diberikan pada Tabel 2.

Tabel 2. Pusat Klaster Fuzzy K-Means

\begin{tabular}{lc}
\hline Cluster & Dimensi \\
\hline Cluster 1 & 1.078 \\
Cluster 2 & 1.437 \\
Cluster 3 & 1.304 \\
Cluster 4 & 1.179 \\
\hline
\end{tabular}

Setelah didapatkan nilai dari masing-masing kluster langkah selanjutnya adalah mencari anggota kelas dari keempat kluster yaitu kelas mata normal, kelas penderita katarak, kelas penderita glaucoma, dan kelas penderita penyakit retina (retina disease). Kemudian semua data diinputkan sehingga diperoleh hasil sebagai berikut:

\begin{tabular}{|cccccccc|}
\hline \multicolumn{2}{c}{ Cluster 1 } & & & & & & \\
& 20 & 26 & 27 & 29 & 31 & 33 & 34 \\
35 & 36 & 37 & 39 & 40 & 42 & 43 & 44 \\
45 & 46 & 48 & 49 & 50 & 57 & 58 & 60 \\
71 & 73 & & & & & & \\
\hline
\end{tabular}

Cluster 1 menunjukkan kelas katarak, dimana terdapat 25 data dalam klaster dan data benar sejumlah 19 data.

\begin{tabular}{|llllllll|}
\hline \multicolumn{2}{|c}{ Cluster 2} & & & & & & \\
84 & 76 & 77 & 79 & 80 & 81 & 82 & 83 \\
93 & 85 & 86 & 87 & 88 & 89 & 90 & 91 \\
94 & 95 & 97 & 98 & 99 & & \\
\hline
\end{tabular}

Cluster 2 menunjukkan kelas penyakit retina (retina disease), dimana terdapat 21 data dalam klaster dan data benar sejumlah 21 data. 


\begin{tabular}{|lrrrrrrr|}
\hline \multicolumn{2}{|c}{ Cluster 3} & & & & & \\
& 1 & 2 & 3 & 4 & 6 & 7 & 8 \\
9 & 10 & 12 & 15 & 16 & 19 & 21 & 22 \\
23 & 24 & 38 & 64 & 78 & 92 & 96 & 100 \\
& & & & & & &
\end{tabular}

Cluster 3 merupakan kelas mata normal yang terdiri dari 23 data dalam klaster dan data benar sejumlah 17 data.

\begin{tabular}{|rlllllll|}
\hline \multicolumn{3}{|c}{ Cluster 4} & & & & & \\
5 & 11 & 13 & 14 & 17 & 18 & 25 & 28 \\
30 & 32 & 41 & 47 & 51 & 52 & 53 & 54 \\
55 & 56 & 59 & 61 & 62 & 63 & 65 & 66 \\
67 & 68 & 69 & 70 & 72 & 74 & 75 & \\
\end{tabular}

Cluster 4 menunjukkan kelas penyakit glaukoma yang terdiri dari 31 data dalam klaster dan data benar sejumlah 19 data.

Selanjutnya akan dicek untuk nilai akurasi dari pengklasteran data yang telah diolah menggunakan persamaan berikut:

$$
\begin{gathered}
\text { Akurasi }=\frac{\text { Jumlah data benar }}{\text { jumlah data keseluruhan }} \times 100 \% \\
\text { Akurasi }=\frac{19+21+17+19}{100} \times 100 \% \\
\text { Akurasi }=\frac{76}{100} \times 100 \% \\
\text { Akurasi }=76 \%
\end{gathered}
$$

Pada penelitian ini didapatkan nilai akurasi sebesar 76\% yang menunjukkan bahwa dimensi fractal box counting pada foto citra fundus retina dapat digunakan dalam menetukan jenis penyakit mata yang diderita seseorang.

\section{Kesimpulan}

Berdasar hasil penelitian diperoleh hasil bahwa deteksi penyakit mata berdasar dimensi fraktal box counting dari foto citra fundus retina dan klasifikasi menggunakan fuzzy k-means menghasilkan akurasi $76 \%$. Ini artinya metode ini berhasil mendeteksi dengan keakuratan sebesar $76 \%$ dalam membedakan mata normal, penderita katarak, penderita glaucoma, dan penderita penyakit retina (retina disease). Sehingga disimpulkan bahwa metode penghitungan dimensi fraktal box counting dari foto fundus retina dapat digunakan untuk menentukan jenis penyakit mata seseorang. 


\section{DAFTAR PUSTAKA}

Alifa, N., \& Juniati, D. (2019). Analisis Jenis Tumor Kulit Menggunakan Dimensi Fraktal Box Counting Dan K-Means. Jurnal Riset dan Aplikasi Matematika (JRAM), 3(2), 71-77.

Asril, B. W., Maison, M., \& Yudertha, A.(2019). Analisis Performa Algoritma Segmentasi Pembuluh Darah pada Citra Fundus Retina. JEPIN (Jurnal Edukasi dan Penelitian Informatika), 5(3), 272-278.

Fitriani, N. A. (2017). Segmentasi Citra Lidar Menggunakan Algoritma K-means. Mathunesa: Jurnal Ilmiah Matematika, 2(6).

Juniati, D., \& Budayasa, I. K. (2016). Geometri Fractal dan Aplikasinya. Surabaya: Universitas Negeri Surabaya.

Juniati, D., Khotimah, C., Wardani, D. E. K., \& Budayasa, K. (2018). Fractal dimension to classify the heart sound recordings with KNN and fuzzy c-mean clustering methods. In Journal of Physics: Conference Series (Vol. 953, No. 1, p. 012202). IOP Publishing

Juniati, D., Budayasa, I. K., \& Khotimah, C. (2020). The Similarity of Iris Between Twins and Its Effect on Iris Recognition Using Box Counting. Commun. Math. Biol. Neurosci., 2020, Article-ID.

Katwarti, E. A. D. (2017). Segmentasi Citra Magnetic Resonance Imaging (MRI) Menggunakan Fuzzy C-Means (FCM). Jurnal Ilmiah Matematika Volume, 2(6).

Munarto, Ri dan Yudono, M. A. S. (2019). Klasifikasi Katarak Objek Optic Disc Citra Fundus Retina Menggunakan Support Vector Machine. Jurnal Ilmiah Setrum 8:1 hal 84-95.

Mustofa, A., Tjandrasa, H., \& Amaliah, B. (2016). Deteksi Penyakit Glaukoma pada Citra Fundus Retina Mata Menggunakan Adaptive Thresholding dan Support Vector Machine. Jurnal Teknik ITS, 5(2), A572-A575.

Safitri, D. W., \& Juniati, D. (2017, August). Classification Of Diabetic Retinopathy Using Fractal Dimension Analysis Of Eye Fundus Image. In AIP conference proceedings (Vol. 1867, No. 1, p. 020011). AIP Publishing LLC. 